\title{
WOMEN RESISTANCE IN EKA KURNIAWAN'S CORAT-CORET DI TOILET SHORT STORIES COMPILATION BOOK
}

\author{
Asri Furoidah \\ Faculty of Humanities, Airlangga University \\ asrifuroidah93@gmail.com
}

\begin{abstract}
'Eka Kurniawan's Corat-coret di Toilet short stories compilation book' consists of twelve short stories telling about light stories of every day life but full of social criticism. Many short stories portrayed imprisoned female characters. Therefore, this research focuses on the actions of female characters in shaping their positions in the story. The data used in this study are in the form of words, sentences, or expressions in short stories showing the dominance of patriarchy towards women and the efforts to get out of domination. The results revealed that patriarchal domination arises in the closest male characters to female characters such as fathers, male friends, and husbands. Women resistance was a form of false resistance, which in turn strengthened the dominance of patriarchy and the dichotomy between men and women. It was found based on the fact that every resistance made by women turned to weaken women themselves.
\end{abstract}

Keywords: Feminism; Patriarchy; Resistance; Women

\section{INTRODUCTION}

Eka Kurniawan is a prolific author widely discussed since the 2000s. Some of his novels and many of his short stories have been translated into various foreign languages. One of his novels, Lelaki Harimau (Tiger Man) was nominated for The Man Booker International Prize award in 2016. In general, Eka Kurniawan works have a broad enough scope both in terms of content and form (Bramantio, 2014: 138). Most of his works present the reality of life in simple but full of topical satire. One of the most famous collections of Eka's short stories is Corat-Coret di Toilet (Scribbling on the Toilet) and it has been translated by Benedict R. O'G. Andersen into foreign languages.

The short story compilation consists of twelve short stories. Most of the short stories have previously been published separately both in printed media and in books from other short stories by Eka Kurniawan. The twelve short stories are Peter Pan (2000), Dongeng Sebelum Bercinta (Fairy Tales Before Making Love) (2000), Corat-Coret di Toilet (Scribbling on the Toilet) (1999), Teman Kencan (Date) (1999), Rayuan Dusta Untuk Marietje 
(Seduction of Lies for Marietje) (2000), Si Orang Gila (The Crazy People) (1999 ), Si Cantik yang Tak Boleh Keluar Malam (The Beautiful Girl Who is not Allowed to Go Out) (2000), Siapa Kirim Aku Bunga (Who Send Me Flowers?) (2000), Tertangkapnya Si Bandit Kecil Pencuri Roti (The Arrest of the Little Bandit Bread Thief) (2000), Kisah dari Seorang Kawan (The Story of A Friend) (1999), Dewi Amor (Goddes of Amor) (2000), and Kandang Babi (Pigs House) (2000).

In Corat-Coret di Toilet's acknowledgment, Mahanaya (2014) wrote that Eka Kurniawan brought a reasonably strong comedy - satirical tone. It is a smart effort to raise small things by changing a trivial thing into a humanitarian problem deserved attention and reap criticism. It is in line with Andersen's statement who stated that the reason for translating the Corat-Coret di Toilet was because this book is one of the most well-known compilations of Eka's short stories and because of his very dark comedy.

Every short story raises a light topic but is filled with various forms of resistance of the characters. These stories appear to be social or political criticism related to the time of writing the first story. Various types of characters are presented to support the intention conveyed by the author. These figures vary from small children, crazy people, activist students, teenage girls, until the toilet walls. From all the topics when talking about female characters, the figure is portrayed as an imprisoned figure and trying to resist the oppressing rules.

In each story, the female characters are always the oppressed party to the events or situation caused by male behavior. Female is always given a passive verb while male is given an active verb. In Dongeng Sebelum Bercinta (Fairy Tale Before Making Love), a female character named Alamanda is betrothed to a cousin by her father since childhood. Alamanda then worked with the cousin and tried to thwart their matchmaking that ended with the cousin falling in love with Alamanda. Entering high school age, she decided to fail her matchmaking by dating but failed. When studying in Java, Alamanda returned to date a friend, but she chose to give up and marry the cousin in the end. After marriage, Alamanda still tried to show her resistance by giving conditions before making love to the cousin.

A similar topic reappeared in Si Cantik yang Tak Boleh Keluar Malam (The Beautiful Girl Who is not Allowed to Go Out). This short story tells about a beautiful girl who studied in a high school and was never allowed to go out at night by her father. The girl tried to use various reasons for going out at night but still prohibited by her father. One day, a school friend asked him to be a lover, she could not answer because of the prohibition to come out at night. To answer the male friend, the girl then ran away from home at night but her attempt failed because the male had chosen another female as his lover. In the end, the girl disappeared and no one knew what was going on with her.

The problems discussed in this paper is: how is the image of women and its relationship with the patriarchy ideology as seen in the short story of Dongeng Sebelum Bercinta (Fairy tale Before Making Love) and Si Cantik yang Tak Boleh Keluar Malam (The Beautiful Girl Who is not Allowed to Go Out). 


\section{THEORETICAL FRAMEWORK}

Literature is a creation of the author and not merely an imitation of events occurring in people's lives. Abrams reveals that "art is like a mirror" which shows that literary work as a genre of art as the social life reflection of the community in which the work was born (1967: 31). However, literature remains the creation of an author as a result of a creative process that produces ideas, concepts, and ideas which might indeed be taken from the surrounding community. Therefore, a literary work conveys an understanding of life in its way (Budianta, 2003: 7).

As a work inspired by human culture and life, patriarchal culture becomes an interesting topic to discuss. According to Bhasin, in social life, gender is related to the concept of patriarchy. The word patriarchy means the power of father (patriarch) as the head of the family, referring to the system of social life. It also means that the father has control over all family members, ownership of goods, sources of income, and the primary decision holders. This social system raises the belief that men are superior to women, so they have the right to control and make women as property. This social system then raises gender inequality (2001: 26). There are various reasons women are affected by patriarchy, and only place women as a companion or even as kanca wingking (a friend in kitchen affairs).

The result of this deeply rooted patriarchal culture is not only in the form of gender injustice and violence but also in the emergence of gender stereotypes. This stereotype dictates the nature and role of men as influential figures and women as weak figures (Gamble, 2010: 422). This cultural system also explains the origin of gender, which is not something that humans have since birth, but something that is done and displayed (Sugihastuti et al., 2010: 4). In other words, gender is inherent in men and women as socially and culturally constructed. This construction continues to change from time to time, which also affects the differences in views and judgments of men and women (Fakih, 2003: 8).

Women oppression is initially begun with an understanding of the differences between women and men. Men assume that women have lower classes below them. The figure considered as a whole person is male while the woman is not. Beauvoir states that humans who always become themselves are men, women never become themselves. It makes women as non-autonomous beings (1992: xviii-xix). Feminism seeks to eliminate opposition between strong and weak groups. So, it can be said that feminism rejects injustice as a result of patriarchal society, rejects history and philosophy as man-centered disciplines (Ratna, 2004: 186).

According to Endraswara, there are five crucial goals in feminist literary criticism related to gender stereotypes. They are 1) revealing the works of past and present women writers, so that the image of women who feel oppressed by tradition is clear; 2) uncovering various pressures on women figures in works written by men authors; 3 ) revealing the ideology of women and men authors, how they view themselves in real 
life; 4) reviewing the gynocritics aspects, namely understanding how the creative process of feminists; and 5) uncovering feminist psychoanalysis aspects, namely why women, both figures and authors, prefer things that are subtle, emotional, full of love, and so on (2008: 146-147).

Moreover, Culler in Sugihastuti states that this concept is used to dismantle the presumption and ideology of male power, which is androcentric or patriarchal, which until now has been assumed to master the writing and reading of literature (2007: 139). In this case, the author views literature with a particular awareness that there is a gender - related to life, culture, and literature (Kurnianto, 2016: 89). Therefore, Ratna argues that women conditions are subordinated to culture. It means that culture causes women to be considered to have a lower position than men, although in the fact that women do work as done by men (2004).

In relation to the previous description, women resistance is very appropriate to uncover the pattern of patriarchal ideology in the short story by Eka Kurniawan. This perspective puts pressure on the position and perception of women who will be able to open the veil about the women lives who have been silenced.

\section{METHODOLOGY}

The research method conducted on the short story by Eka Kurniawan was a descriptive qualitative. The analytical method used is reading and understanding deeply about the Short Story of Dongeng Sebelum Bercinta (Fairy Tale Before Making Love) and Si Cantik yang Tak Boleh Keluar Malam (The Beautiful Girl Who is not Allowed to Go Out). The data of this study are all forms of expressions in the form of words, phrases, and discourses originating from those two short stories. Through the text strategy, the author's point of view will be expressed in voicing his thoughts regarding the issue of patriarchal ideology and the struggle of women in breaking down the ideological establishment.

The specific reading focuses on female characters in the story to find a form of resistance made by female figures to patriarchal ideology. The resistance is based on every action from a female character in solve the problems. Besides, the forms of feelings, intentions and final result of the struggle which are then connected with the representation of women struggles in male writers' literary works are also analyzed. From the whole series, results will be found on the meaning of resistance carried out by women figures. Finally, a conclusion is drawn from findings based on women resistance thought.

\section{FINDINGS AND DISCUSSION}

\section{Resistance of Women Figures to Patriarchal Ideology}

Dongeng Sebelum Bercinta (Fairy Tale Before Making Love) illustrates a female figure -the main character in the story - struggling against a strict patriarchal culture. She lives in a family environment that always matches their kids with their relatives since 
childhood. Realizing this phenomenon, she tries to fight by thwarting the matchmaking. However, the cousin finally falls in love with her and sincerely wants to marry her.

But whatever happened, she finally became his wife. She was not a strong girl who was able to rebel against the curse of the father. She was not a stubborn girl when facing her cousin who almost cried begging her to want to become a wife. (Kurniawan, 2014: 14)

This part of the short story shows that women have always been an alienated party. The dichotomy of the roles between men and women places women only with a narrow and non-free and bound role. As the meaning of patriarchy itself belongs to the father, which is a man, then it can be interpreted here that women in their overall roles will always be bound by the actions of men. Everything they want must be following their fathers' dreams.

The female figure and her position confined by the value of a father also appeared in Si Cantik Yang Tak Boleh Keluar Malam (The Beautiful Girl Who is not Allowed to Go Out). The 17-year-old girl must obey her father's ban to go out at night. When she asked permission to go out as her birthday gift, her father makes the request come true, but she has to go out instead with her parents. It means that she could not get along with friends of her age. No matter how beautiful the hatred of the rules is, she still cannot resist her father's will.

Until the next nights, she missed the routine that began to suck. He replayed several Tom \& Jerry series until she thought she had seen it more often than anyone, even more often than Hanna-Barbera himself. (Kurniawan, 2014: 57-8)

Alamanda and Si Cantik are described as weak girls who cannot do what they want to. It is consistent with the main idea of patriarchy manifesting a woman with subtle and fragile traits. The idea seems dominant because indeed, women always become inferior, and so they should be. Any rules made by fathers of the characters are still expressed as something beautiful. So, we can see that all about men are good, while all about women are low and do not need attention. In other words, women must follow men decisions.

However, there is some women resistance showed by the female characters in these two short stories. First resistance is by fighting their conditions with negotiations. Alamanda, for example, tries to cooperate with her cousin, while Si Cantik talks to her father for the looseness of the rules. It can be seen in the following excerpt:

The mother sighed and did not give up. "You remember. Dear. We sometimes go out at night. Watch a concert or join a party. No one robbed me. And you don't rape me too. And you know, I only take cold medicine, nothing more."

"Yeah ..." said the father, yawning. "That's because you were going out with me first." The sentence ended with a fine snoring. (Kurniawan, 2014: 60) 
The above excerpt explains that there is no guarantee that a woman will be safe without her father. The dominance of patriarchy in the form of fatherhood seems very clear here.

Another resistance is planned when the negotiation does not work. Alamanda, for example, tries to fight her father by dating her friends in high school. This resistance shows the strength of Alamanda because she manages to build a relationship with the most favorite male in school but it is failed because the man is afraid of her father. Next, the failure of previous resistance does not stop Alamanda efforts to escape the arranged marriage. She starts another new relationship with her friend at university. With this man, Alamandah has a wonderful and happy time. This rebellion can be said to be quite successful because it can make her father furious after hearing the news.

On the other hand, Si Cantik is fed up with her father rules, especially when she starts falling in love with a school friend, Romeo. Many times, Romeo expresses his love and asks her feeling but she keeps asking Romeo to wait because of her father. The climax resistance is when she plans to run away from home as a form of rebellion against her father.

Si Cantik decided to rebel a little.

On the night of her school-grade art performance, "Si Cantik quietly made a plan". When her parents were watching political talk on television, Si Cantik locked the door to her room. Then, she turned on the radio and chose the station that broadcast lullabies songs. Two minutes later he had jumped from the window, stood on the side of the road and breathed in the night air which was full of freedom. (Kurniawan, 2014: 63)

After carrying out various attempts at rebellion against her father, Alamanda finally marries her cousin. But she proposes some conditions to the cousin to give a fairy tale before making love. It is another form of defense of Alamanda to avoid having physical contact with her cousin. The reason for using the fairy tale is as the culmination of her resistance to patriarchal domination which made her should marry a man she does not love and strengthen her resistance. This time, she succeeds.

There is a unique pattern in Alamanda's and Si Cantik's resistance. Alamanda tries to get rid of the arranged marriage since her childhood. While Si Cantik wants the freedom to go out and do everything she has never done. Regardless of the impact and possible goals or reconsidering the reasons for the prohibition applied by their fathers, they try various ways to gain freedom. The two forms of resistance show the similarity of patterns in the form of spontaneous actions taken by the two female characters.

In a patriarchal culture, women are always the subordinate party and it puts women only in the domestic environment. In these two short stories, the domestic environment is meant by the scope of a father's power. Various forms of rebellion are carried out by female characters to escape from the dominance of patriarchy in the way of an irrational rule from a father. It is the result of deep-rooted thinking, placing women on the dark and repressed side because they must always obey the norms determined by 
the dominant party, namely men. Being in a long shadow of men brings saturation and rejection of women. The result is the emergence of a rebellion effort from the oppressed party to free themselves from the shackles of the binding norms or rules. In the context of the two short stories, the rules in question are the rules made by the father figures in the effort to fully determine the way of life of female figures. While the resistance efforts emerge from female characters emerges in the form of negotiations to escape.

The resistance makes Alamanda and Si Cantik as figures who have the courage and determination to achieve their desires. On the contrary, a resistance carried out spontaneously are impulsive and not minded. A resistance without purpose and careful planning will ultimately end in vain. It eventually strengthens the image of irrational women who only act according to their will. This description is very in line with the image of women formed by patriarchal culture.

\section{The Perpetuation of the Patriarchal Ideology through the Apparent Resistance of Female Figures}

The resistance carried out by Alamanda and Si Cantik in both short stories is expected to be able to undermine the longevity of patriarchal ideology and bring out the image of a woman. The illustration expected to emerge is a woman having will and purpose of life, rationally thinks and able to compete equally with men. Every act of resistance carried out by the female main characters in these two short stories does not seem to fully make them succeed in undermining the patriarchal ideology and making women as whole human beings.

Alamanda never does any resistance herself; she always involves a man. So, it can be said that in fighting against patriarchal ideology, she borrows men power. Therefore, the question of the existence of women reappears. Since her first resistance, Alamanda openly asks her boyfriend to take her away. She does not try to deal with and resolve the problem itself but instead chooses to leave. Her intention shows how weak she is in front of the patriarchal confines.

The second rebellion makes Alamanda confused about what to do. Returning to her father means being subdued by the confinement of patriarchal domination that will tie her for life or go with her lover which means to be free but live in poverty. The choice taken by Alamanda once again proves that she is still a woman who does not have the goals and desires in her life. Knowing that Alamanda will be married in the near future, her boyfriend gives a choice.

"Now it's up to you, Alamanda. If you mate with your cousin, you might live well. You will not be ostracized by your father, mother and brothers. You have a big house, a vehicle, can watch MTV, eat at a cafe and have a beautiful life. Or do you choose to marry me? Your father will not think of you as a child anymore and you will be forced to live in my cottage which is only three times three meters and if it rains heavily a little wet in the left corner. You also have to wash your own clothes, also have to eat not 
nice dish, because we will not have much money. But you have a bonus: a romantic and intelligent husband, hahaha ... (Kurniawan, 2014: 19)"

This is reinforced by the description in the story "Alamanda did not dare to take a romantic and intelligent husband and decided to go home as a losing girl" (Kurniawan, 2014: 19). This statement further marginalizes women because if women are previously imagined, they are always pressured and dictated in their lives, so they have no choice but to obey.

At this stage, women have been given a choice to be able to be free from patriarchal domination meaning given the right and freedom to choose. But when this power is given, women decide to surrender and re-enter the patriarchal domination. It seems clear that they consider themselves do not have the strength and do not deserve the power. For example, when Alamanda finally surrenders and then accepts the marriage to her cousin. The return of Alamanda to her father and her acceptance of the marriage further perpetuates the existing of patriarchal culture.

The other resistance carried out by Alamanda not to make love to her husband instead because of her fear of losing virginity before marrying her husband.

"Are you crazy or mad? Finish your fairy tale tonight too and you feel how it feels to make love. Look, you're not shrewd Syahrazad. In time, your husband will get bored and maybe he decides to cut your head off with a machete."

"But I'm afraid."

"Afraid of what?"

"Afraid he knows that I'm not a virgin." (Kurniawan, 2014: 21).

This reason further reinforces that women are described as being full of fear in themselves. Therefore, she cannot freely determine her way of life.

On the other hand, the resistance of Si Cantikfurther strengthens patriarchal dominance in the short story. At first, the resistance triggered by the father's restraint to Si Cantik. In the early days, it is still carried out from inside the house meaning that she could be free without leaving the area of father's dominance. But when she finally falls in love with Romeo, the determination to escape from the house or to flee from the area of father's domination appears.

Days after that, Romeo kept asking whether his love was responded or not.

That reality is a burden on itself for Si Cantik.

Si Cantik decided to rebel a little.

On the night of his school-grade art performance stage, Si Cantik makes the plan secretly, ... she turned on the radio and chose the station that broadcast lullabies songs. Two minutes later she had jumped from the window, stood on the side of the road and breathed in the night air which was full of freedom.

She wants to meet her Romeo and return his love. (Kurniawan, 2014: 62-3)

It can be said that what is done by Si Cantik is not pure for herself but for the sake of a man. It is evident from the absence of a clear plan that is organized about what she 
will do after being free. The nature of an impulsive woman is easily carried away and not rational to get affirmations.

Apart from the resistance made by Si Cantik, the end of the short story also has a significant portion in strengthening patriarchal dominance. After escaping from home, she must be disappointed again to find Romeo has been with Juliet. Here, si Cantik is a person who is defeated and cannot reach the goal even after running away from home. The end of the short story is one big aspect that must be considered.

Since that night, it is said that Si Cantik has never returned home. Has Si Cantik decided to be the night lover as she wishes? Some people still often see it at night in pubs and discos, or in the lobby of a hotel. Some other people saw her on the roadside under full moonlight stopping a taxi or walking with a potbellied old man. There was a rumor she became a night butterfly. But most people believe that she died of suicide and that often seen her ghost is still curious ....

An the end, no one knows about Si Cantik after the escape. It indicates that Si Cantik disappearance and her previous various efforts are made in order to be free from the power of her father.

In the end of the story, Si Cantik shows a message or also a warning about the strength of patriarchal domination which cannot be eliminated. It appears in the two short stories that no matter how strong a woman tries to break away from patriarchal domination, the effort will not give satisfactory results. Women can only move from one dominance to another domination, even if it is not according to their wishes. Also if in the end there is a woman who has a strong determination to get out of that domination, the result will only harm the woman as happened to Si Cantik. The woman will end up without a clear and alienated fate so that she is no longer recognized by her environment. At this point, it can be said that the existence of a woman is only limited to become a legitimacy for the strength of the patriarchal domination, not for the interests of the women themselves.

Moreover, names for the main female characters have illustrated that women in this story are not considered as human beings but objects. This object is then used as a tool to perpetuate the patriarchal power that previously existed. The name Alamanda is one type of ornamental flower used as an ornamental flower because of its beautiful shape. While the other female characters are named Si Cantik, the beautiful girl. Beautiful itself is an adjective pinned to both humans and objects that have an attractive appearance. It seems that women here are aligned with something which is used as decoration or complementary and not the main thing. The meaning is that women are not the main subject, but complementary.

The portrayal of female characters as illustrated by the efforts of resistance carried out by Si Cantik and Alamanda is increasingly in line with those formed by patriarchal understanding over the years. The ideology conveyed by the text is that women, like any woman's efforts in fighting and struglling, will never be able to free themselves from 
patriarchal domination. Everything that is done by women always depends on men. As far as any woman goes, she will eventually return home. If in the end the women fight as a form of resistance to dominance, then the effort will not provide satisfactory results. Even if someone is brave enough to run away, her fate will end up being alienated and increasingly not recognized. Besides, the power of men is intact and undeniable, and women are a complementary tool to perpetuate that power.

\section{CONCLUSION}

It is found that the bond of patriarchal domination in the form of a father makes women try to resist escaping the bond. The resistance is carried out as an effort to be free and express their desires. Ironically, the resistance forms their characters as an impulsive figure and do not think in determining the way of life. It can be concluded that the resistance carried out by two female figures in the story is a form of apparent resistance used to strengthen the position of male domination over women.

Aside from the apparent resistance formed through female characters, patriarchal dominance also appears at the end of the two short stories. At last, it is revealed that the ideology conveyed is patriarchal domination. Women, like whatever they are fighting and struggling will never be able to release themselves from that domination because there is indeed a position to be a compliment. Therefore, everything that is done by women depends on what is determined by men. If a woman leaves, the choice is to go back to the house, that is, an area that can be referred to as domestic or deep, or if she does not become alienated and loses her existence.

\section{REFERENCES}

Abrams, M.H. 1967. The Mirror and the Lamp. London: Oxford University Press

Beauvoir, S.d. 1992. 'The Second Sex'dalam Magie Humm (Ed.), Feminism a Reader. New York: Harvester Wheatsheaf

Bhasin, K. 2001. Memahami Gender. (Hussein, Moh. Zaki, penerjemah.) Jakarta: Teplok Press

Bramantio. “Puitika Cerpen-cerpen Eka Kurniawan.” Mozaik 14 (2): 137-153

Budianta, Melani, dkk. 2003. Membaca Satra. Magelang: Indonesia Tera

Endraswara, Suwardi. 2008. Metode Penelitian Sastra: Epistemologi, Model, Teori, dan Aplikasi. Yogyakarta: Medpress

Fakih, Mansour. 2003. Analisis Gender dan Transformasi Sosial. Yogyakarta: Pustaka Pelajar

Gamble, Sarah. 2010. Pengantar Memahami Feminisme dan Postfeminisme. Yogyakarta: Jalasutra

Kurnianto, Ery Agus. 2016. Resistensi Perempuan Terhadap Wacana Ratu Rumah Tangga dalam Cerpen Intan Paramaditha. Atavisme, Vol. 19, No. 1, Edisi Juni, 2016: 88-101

Kurniawan, Eka. 2014. Corat-coret di Toilet. Jakarta: PT. Gramedia Pustaka Utama 
Ratna, Nyoman Kutha. 2004. Teori, Metode, dan Teknik Penelitian Sastra. Yogyakarta: Pustaka Pelajar

Sugihastuti. 2007. Teori Apresiasi Sastra. Yogyakarta: Pustaka Pelajar

Sugihastuti dan Itsna Hadi Setiawan. 2010. Gender dan Inferioritas Perempuan. Yogyakarta: Pustaka Pelajar

Wahyuni, Dessy. 2013. Perempuan dengan Segala Luka dalam Kumpulan Cerpen Suatu Hari Bukan di Hari Minggu. Atavisme, Vol. 16, No.2, Edisi Desember 2013: 247-257

Wikipedia. 2017. Allamanda Cathartica.

https://id.m.wikipedia.org/wiki/Allamanda_cathartica. Diakses pada 5 Juli 2017 
82 I Asri Furoidah 